\title{
Characterization and application of orange peel as an adsorbent for cationic dye removal from aqueous solution
}

\author{
Caracterização e aplicação de casca de laranja como adsorvente para \\ remoção de corante Catiônico em solução aquosa
}

\author{
Aline Haas' ${ }^{(1)}$, Eliane Pereira dos Santos' \\ ' Universidade Federal de Santa Maria- Campus de Frederico Westphalen, Frederico Westphalen, RS, Brazil
}

\begin{abstract}
With the great generation of colored effluents, several methods for the removal of the color are used, being one of them the method of adsorption in solid medium. In this paper, the in natura orange peel was used as the alternative biomass for the adsorption process of methylene blue, which was characterized by moisture content, $\mathrm{pH}$, apparent density, iodine number, and methylene blue index. To determine the adsorptive capacity of the methylene blue dye, $\mathrm{pH} 7$ was obtained as favorable, the adsorption process showed an adsorption of $82 \%$ of the methylene blue dye and a 10 min equilibrium time, where the Freundlich isotherm presented a better adaptation to the adsorption process in orange

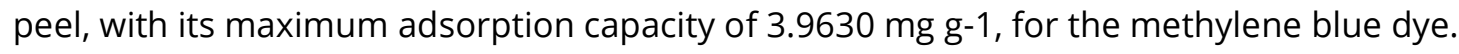

Keywords: Alternative biomass; Adsorption; Activated carbon; Dye; Isotherms

\section{RESUMO}

Com a grande geração de efluentes coloridos, vários métodos para a remoção da cor são utilizados, sendo um deles o método de adsorção em meio sólido. Neste trabalho foi utilizada a casca de laranja in natura como biomassa alternativa para o processo de adsorção, a qual foi caracterizada através do teor de umidade, $\mathrm{pH}$, densidade aparente, número de iodo e índice de azul de metileno. Para determinação da capacidade adsortiva do corante azul de metileno, obteve-se o pH 7 como favorável, o processo de adsorção apresentou uma adsorção de $82 \%$ do corante azul de metileno e um tempo de equilíbrio de 10 min, onde a isoterma de Freundlich apresentou uma melhor adaptação ao processo de adsorção em 
casca de laranja, sendo a sua capacidade máxima de adsorção de 3,9630 mg g-1, para o corante azul de metileno.

Palavras-chave: Biomassa alternativa; Adsorção; Carvão ativado; Corante; Isotermas

\section{INTRODUCTION}

The growth of the textile sector increases the use of dyes and consumption of water, thus the considerably high volume of colored wastewater generated. Contamination of any amount of colored compounds present in dyes induce a color variation of aqueous solutions, therefore visibly modifying the color aspects of industrial effluents (BELTRAME, 2000).

Synthetic dyes cause a big environmental problem since they can be toxic. The contamination of aquatic systems affects the penetration depth of solar radiation, consequently reducing the photosynthetic activity of the system.

The methylene blue dye produces colored cations in solution due to its solubility in water; therefore, the scientific literature refers to it as a cationic dye (Guaratini e Zanoni, 2000). Once the dye is a toxic compound in the environment, the removal of it becomes necessary due to its related environmental problems (BUKALLAH et al, 2007).

Many researchers have applied adsorption techniques as post-treatment in the removal of dyes (AGUIAR, 2012). Adsorption is a unit operation that involves the contact between a fluid phase to a solid phase, originating a mass transfer from the fluid phase to the surface of the solid. As a result, there is a tendency of accumulation of one substance on the surface of the other one (FRANCISCHETTI, 2004).

According to Kermer and Richter (1995, apud BELTRAME, 2000) adsorption is suitable for apolar and cationic products removal. The substance that accumulates on the interface is called "adsorbate" and the solid substance on which the adsorption occurs is named "adsorbent" (SILVA, 2012). 
The selection of an adsorbent with a high adsorption capacity and removal efficiency is necessary to an efficient adsorption process. This adsorbent must be available in big amounts to a low cost (ROYER, 2008).

The activated charcoal is one of the most used commercial adsorbents mainly due to its high adsorption capacity, low thermal reactivity and resistance to great $\mathrm{pH}$ variations in the medium (VASEQUES et al., 2009). However, due to the elevated costs of activated charcoal and the great volume of effluents generated by the textile industry, there is a need for studies with alternative adsorbents produced with biomass constituted by natural residues.

Ferrari (2009) states that the use of orange bagasse in adsorbent form would be an alternative to the elevated amount of wastes produced. According to some studies (ARAMI et al., 2005; SIVARAJ et al., 2001, NAMASIVAYAM et al., 1996 apud FERRARI, 2009), the orange peel presents natural adsorptive characteristics similar to the activated charcoal.

Therefore, the objective of this study was to characterize and to evaluate the applicability of orange peel biomass as an adsorbent to remove methylene blue textile dye through characterization test of an adsorbent prepared from in natura orange peel and adsorption isotherms of the dye.

\section{Methodology}

\subsection{Sample collection and preparation}

This paper presents in natura orange peel (biomass) as an alternative adsorbent material. The adsorbent collection occurred in a rural property located in the city of Erval Seco - RS.

After collection, the sample was dried in an oven model 4 of the brand Brasdonto at a temperature of $50{ }^{\circ} \mathrm{C}$ for approximately $72 \mathrm{~h}$ until the sample reached a constant mass. After the drying, the sample was comminuted using a knife grinder type Willye - 
SL 31. (Adapted from Ferrari 2009). Thenceforth, the mean sample diameter was evaluated by using Tyler test sieves. Sieves with screen sizes of 65 and 200 mesh were used. The sample retained in the 65-mesh sieve was separated from the sample retained in the 200-mesh sieve and the sample that passed through the 200-mesh sieve.

\subsection{Characterization of the adsorbent}

The iodine number, methylene blue index, $\mathrm{pH}$, moisture content and bulk density determined the characterization of the sample.

\subsubsection{Moisture content}

The determination of moisture content in the adsorbent was based on the Brazilian Association of Technical Standards ABNT NBR 12077 MB-3414 (1991). Initially, circa $5.0 \mathrm{~g}$ of adsorbent sample was weighted in a porcelain capsule dried in an oven at $130^{\circ} \mathrm{C}$ for $30 \mathrm{~min}$. After that, the sample was placed in an oven at $130^{\circ} \mathrm{C}$ for $3 \mathrm{~h}$. Then, the sample was shifted to a desiccator with silica gel to achieve room temperature. Finally, the porcelain capsule containing the sample was weighted on a scale with 0.0001 g precision.

The porcelain capsule containing the sample was placed again in the oven for 3 $\mathrm{h}$ and the same the drying and weighing procedure was applied until two successive weighings did not present a difference superior to $0.01 \mathrm{~g}$. The determination was carried out in triplicate.

\subsection{2 $\mathrm{pH}$}

The adsorbent $\mathrm{pH}$ was determined by adapting the Japanese Industrial Standard, JIS K 1474 - 1991. The granulometry used to determine $\mathrm{pH}$ varied from 0.208 to 0.074 $\mathrm{mm}$. Initially, a Petri dish was dried in an oven at $130^{\circ} \mathrm{C}$ for $30 \mathrm{~min}$. After that, $5 \mathrm{~g}$ of the absorbent was weighed in the Petri dish, then it was dried in an oven for $3 \mathrm{~h}$. At the end 
of the dry period, the dish was placed in a desiccator until it reached a constant temperature. Finally, the dish was weighed again and the adsorbed moisture was determined.

After determining the sample moisture, $3.000 \mathrm{~g}$ of the adsorbent was weighed plus the adsorbent moisture percentage in a beaker. Then, $100 \mathrm{~mL}$ of boiling water was added and the beaker was placed on a hot plate to boil for $5 \mathrm{~min}$. After the boiling period, the beaker was removed from the hot plate and left to stand until it reached room temperature. Finally, $100 \mathrm{ml}$ of distilled water was added in the beaker and then the orange peel $\mathrm{pH}$ was determined using the $\mathrm{pH}$ meter Tekna T-1000.

\subsubsection{Apparent density}

The apparent density was determined by the adaptation of the Brazilian Association of Technical Standards ABNT NBR 12076:1991.

Firstly, an adsorbent mass enough to fill a $100 \mathrm{ml}$ beaker was dried in an oven at $50{ }^{\circ} \mathrm{C}$ - instead of $100{ }^{\circ} \mathrm{C}$ established by the standard - for 3 h. A $100 \mathrm{~mL}$ graduated cylinder was also dried at $130{ }^{\circ} \mathrm{C}$ for $30 \mathrm{~min}$. After the adsorbent and the graduated cylinder cooled down to room temperature, the graduated cylinder was weighed in the precision of $\pm 0.0001 \mathrm{~g}$ and the value was recorded. The graduated cylinder was then filled with the dried adsorbent until the $100 \mathrm{~mL}$ mark and it was weighed. The value encountered was subtracted by the graduated cylinder mass, so the adsorbent mass was determined. The material contained in the graduated cylinder (orange peel) was compacted to the point that no more compaction of the adsorbent volume was possible. The volume corresponding to the occupied mark after the compaction was recorded and then the apparent density was calculated.

\subsubsection{Determination of Iodine Number and Methylene Blue Index}

The determination of iodine number was made by the adaptation of standard ABNT MB-3410; adsorbent with a mean particle size of $0.074 \mathrm{~mm}$ (200 mesh) was used. 
Firstly, the sample was dried in an oven at $50{ }^{\circ} \mathrm{C}$ until constant mass. Then, $5.000 \pm 0.001$ $\mathrm{g}$ of the orange peel sample was weighed in an Erlenmeyer in which was added $50 \mathrm{~mL}$ of $1: 5(\mathrm{v} / \mathrm{v})$ hydrochloric acid solution and it was swirled until the sample became wetted. The Erlenmeyer was heated and the orange peel and acid solution boiled for approximately $30 \mathrm{~s}$. After cooling to room temperature $100 \mathrm{~mL}$ of iodine solution was added into the Erlenmeyer, then it was stoppered and shaken vigorously with circular movements for $30 \mathrm{~s}$. Subsequently, the solution was filtered by gravity in a glass funnel with qualitative filter paper "into a beaker".

The filtrate concentration was determined by titration method. Then, $50 \mathrm{~mL}$ of the filtrate was pipetted into a $250 \mathrm{~mL}$ Erlenmeyer flask. The titration of the filtrate was made with standardized sodium thiosulfate solution until the solution was a pale yellow. After that, approximately $2 \mathrm{~mL}$ of a starch indicator solution was added in and then the titration with sodium thiosulfate proceeded until one drop produced a colorless solution. The total volume of sodium thiosulfate solution used calculated the iodine number.

The methylene blue number (MBN) was determined by the adaptation of the standard JIS K 1474 of Japanese Industrial Standard. Initially, $1.0 \mathrm{~g}$ of the methylene blue dye was dried in an oven at $110^{\circ} \mathrm{C}$ for a period of $4 \mathrm{~h}$. After the end of the period, it was cooled in a desiccator containing silica gel until it reached room temperature. Then, the mass of the methylene blue dye was determined and the calculation was performed to determine the unit percentage using equation 4. Subsequently, a standard methylene blue solution was prepared with $1.2 \mathrm{~g}$ of dye in a final volume of $1 \mathrm{~L}$ in a phosphate solution, which has a function of stabilizing the $\mathrm{pH}$ of the solution in 7 .

The construction of the calibration curve for the methylene blue dye was performed by dilutions of standard methylene blue solution, with $10 \mathrm{~mL}$ of the standard solution being initially placed in a $500 \mathrm{~mL}$ volumetric flask and the volume filled with the buffer solution. From the standard methylene blue solution, dilutions were made 
in $500 \mathrm{~mL}$ flasks to construct the calibration curve. The curve was constructed with concentrations of $0.24 ; 0.48 ; 1.2 ; 2.4$ and $4.8 \mathrm{mg} \mathrm{L}^{-1}$ of methylene blue, a phosphate buffer solution was used as a solvent.

The absorbance readings were performed using an Analytik Jena model Specord 50 Plus spectrophotometer at a wavelength of $665 \mathrm{~nm}$.

For determining the methylene blue number, the following adsorbent masses were weighed: $0.600 \mathrm{~g}, 0.610 \mathrm{~g}, 0.620 \mathrm{~g}$, and $0.630 \mathrm{~g}$. The determination was performed in triplicate. Previous tests where the dye concentration, which the recommended by the standard was $1,200 \mathrm{mg} \mathrm{L}^{-1}$, resulted in a very high remaining concentration. The recommended concentration lead to nonlinear results, so the experiment was set to a dye concentration of $20 \mathrm{mg} \mathrm{L}^{-1}$. Each of the adsorbent masses was transferred to Erlenmeyer flasks and $25 \mathrm{~mL}$ of the $20 \mathrm{mg} \mathrm{L}^{-1}$ methylene blue working solution was added to each of them. The mixtures were shaken in an orbital shaker for $30 \mathrm{~min}$ at 160 rpm. After being shaken, the mixtures were filtrated by gravity through a folded filter paper into a beaker. Thereafter, the samples were transferred to $1 \mathrm{~cm}$ light path glass cuvettes. The calibration curves were determined through methylene blue remaining concentration in each Erlenmeyer flasks.

\subsection{Determination of adsorption capacity}

\subsubsection{Determination of $\mathrm{pH}$ influence}

The experimental test evaluated the influence of the $\mathrm{pH}$ variable of the solution in the adsorption process. In this way, adsorbent particles with a mean particle size of $0.208-0.074 \mathrm{~mm}$ were used. The $\mathrm{pH}$ influence tests were based on evaluating the adsorption of the dye in the $\mathrm{pH}$ range from 1 to 14 . The $\mathrm{pH}$ was adjusted using $\mathrm{NaOH}$ $\left(0.1 \mathrm{~mol} \mathrm{~L}^{-1}\right)$ and $\mathrm{H} 2 \mathrm{SO} 4\left(0.1 \mathrm{~mol} \mathrm{~L}^{-1}\right)$ solutions.

The tests were performed in duplicates by mixing $25 \mathrm{~mL}$ of $5 \mathrm{mg} \mathrm{L}^{-1}$ dye solution, prepared with distilled water, with $0.5 \mathrm{mg}$ of adsorbents in Erlenmeyer. The flasks were 
let sit for $2 \mathrm{~h}$ at room temperature. After the solutions were filtered in a qualitative filter paper and the remaining dye concentration in the solution was determined by UV-Vis spectrophotometry.

For determining the remaining concentration of methylene blue in solution, a calibration curve was made by preparing six solutions of concentration $0.24 \mathrm{mg} \mathrm{L}^{-1} ; 0.48$ $\mathrm{mg} \mathrm{L}^{-1} ; 0.96 \mathrm{mg} \mathrm{L}^{-1} ; 2.4 \mathrm{mg} \mathrm{L}^{-1} ; 4.8 \mathrm{mg} \mathrm{L}^{-1} ; 4.8 \mathrm{mg} \mathrm{L}^{-1}$; and $9.6 \mathrm{mg} \mathrm{L}^{-1}$. The reading of absorbance was used to plot a scatter plot of absorbance versus concentration of each solution. The quantity of remaining dye in solution is calculated through a linear equation obtained with the calibration curve. After determining the remaining concentration of methylene blue as a function of $\mathrm{pH}$, a photometric spectral scanning was performed at different pHs (1, 3, 5, 7 and 9) using three different solutions, named $A, B$, and C:

A: $25 \mathrm{~mL}$ of $5.0 \mathrm{mg} \mathrm{L}^{-1}$ methylene blue solution;

B: $0.5 \mathrm{~g}$ of orange peel in $25 \mathrm{~mL}$ of water;

C: $0.5 \mathrm{~g}$ orange peel $+25 \mathrm{~mL} 5.0 \mathrm{mg} \mathrm{L}^{-1}$ methylene blue solution.

An equilibrium time of approximately $2 \mathrm{~h}$ was set prior to the reading of each scanning spectrum.

\subsubsection{Equilibrium time}

The adsorption equilibrium time was determined by experiments in which the adsorbate and adsorbent concentration were constant and the contact time varied in the following intervals: $1,3,5,10,15,25,35,60,70,100$ and 130 min.

$1 \mathrm{~g}$ of the adsorbent was distributed in three Erlenmeyer (triplicate) containing $500 \mathrm{~mL}$ of $5.0 \mathrm{mgL}^{-1}$ methylene blue solution. After adding the methylene blue solution in the adsorbent, the mixture was kept under stirring on a magnetic stirrer, with speed 
adjusted to ensure that the adsorbent was kept in suspension until each contact time was reached.

The experiment temperature was set at a constant temperature of $23^{\circ} \mathrm{C}$ in an acclimatized room.

After each stipulated stirring time, a portion of the sample was filtered on filter paper and submitted to UV-Vis spectrophotometer determination. The equilibrium time was defined as the minimum time in which the values of the remaining concentration presented no significant change.

\subsubsection{Construction of adsorption isotherms}

In order to know the adsorbent efficiency, the adsorption isotherms were determined through the adaptation of ASTM D 3860 - 98.

Table 1 presents the adsorbent masses used in the assay according to the sample concentration and volume

\begin{tabular}{|c|c|c|}
\hline $\begin{array}{l}\text { Adsorbate concentration } \\
\left(\mathrm{ml} \mathrm{L}^{-1}\right)\end{array}$ & Sample Volume $(\mathrm{mL})$ & $\begin{array}{l}\text { Adsorbent Mass Used } \\
\text { (h) }\end{array}$ \\
\hline 5 & 500 & $\begin{array}{l}0.05 ; 0.10 ; 0.25 ; 0.50 ; \\
1.00\end{array}$ \\
\hline
\end{tabular}

Source: Authors (2015)

The adsorption isotherms were determined through assays, using adsorbent with a mean particle size of 0.208 - 0.074. The orange peel and methylene blue solution presented $\mathrm{pH}$ values around 7, hence the $\mathrm{pH}$ was not adjusted. The masses presented in Table 1 were weighed on a precision scale and added in Erlenmeyer flasks, and then $500 \mathrm{~mL}$ of the $5.0 \mathrm{mg} \mathrm{L}^{-1}$ methylene blue dye solution was then transferred to each of the Erlenmeyer flasks. These solutions were stirred for $10 \mathrm{~min}$. After the stirring period, aliquots were pipetted to cuvettes and the absorbance was read in a 
spectrophotometer UV-Vis. The concentration was calculated through the linear equation.

Experimental data of qe $\left(\mathrm{mg} \mathrm{g}^{-1}\right)$ variation as a function of $\mathrm{Ce}\left(\mathrm{mg} \mathrm{L}^{-1}\right)$ were fitted to Langmuir and Freundlich equations.

\section{3. 4 Column chromatography}

The separation assays using column chromatography were made to separate the mixture to colored compounds in the solution after the adsorption process.

Firstly, $1.00 \mathrm{~g}$ of the adsorbent was weighed in an Erlenmeyer and $25 \mathrm{~mL}$ was added in the $5 \mathrm{mg} \mathrm{L}^{-1}$ methylene blue solution, then the solution was shaken for $10 \mathrm{~min}$ in a mechanical shaker. Then the solution was filtered on filter paper.

The glass column used in the chromatography had a height of $7 \mathrm{~cm}$ and a diameter of $15 \mathrm{~mm}$. Florisil was placed in $4 \mathrm{~cm}$ of the column as the stationary phase, after that the mobile phases were added in. The mobile phases consisted of water, ethanol, toluene, ethyl acetate and hexane in order to separate the colors.

\section{RESULTS AND DISCUSSION}

\subsection{Sample characterization}

Table 2 shows the values of Moisture Content, pH, Apparent Density, lodine Content, and Methylene Blue Number obtained through the characterization of the adsorbent.

Table 2 - Adsorbent characterization

\begin{tabular}{ccccc}
\hline $\begin{array}{c}\text { Moisture } \\
\text { Content - Wet } \\
\text { Basis (\%) }\end{array}$ & pH & $\begin{array}{c}\text { Apparent } \\
\text { Density (g } \\
\left.\mathbf{c m}^{3}\right)\end{array}$ & $\begin{array}{c}\text { lodine } \\
\text { Number (mg g- } \\
\text { 1) }\end{array}$ & $\begin{array}{c}\text { Methylene Blue } \\
\text { Number }\left(\mathbf{m L ~ g}^{-1}\right)\end{array}$ \\
\hline 74.37 & 5.21 & 1.15 & 158.88 & 40 \\
\hline
\end{tabular}

Source: Authors (2015) 
Orange peel can contain up to $85 \%$ of water (TRIPODO, 2004), according to Table 2 , it is possible to observe that the adsorbent in this study presented a high moisture content. Drying the sample is necessary for reducing the residual liquid content. Therefore, lower moisture content improves the adsorption process once it releases adsorption sites.

The $\mathrm{pH}$ value of the orange peel demonstrated that the adsorbent has an acid surface. Acid surfaces are characterized by the presence of functional groups such as group carboxyl.

Due to the use of the adsorbent with a mean particle size of $0.074 \mathrm{~mm}$, a large reduction of the adsorbent volume is observed in the beaker and, therefore, there is an increase of the apparent density in relation to the granular activated carbon, Loureiro (2012) emphasizes that the same has an apparent density around $0.50 \mathrm{~g} \mathrm{~cm}^{-3}$. This difference between apparent densities of the adsorbents is mainly due to the granulometry that was used.

The iodine number is used to represent the number of micropores in an adsorbent sample. By the iodine number found in this study $\left(158.88 \mathrm{mg} \mathrm{g}^{-1}\right)$, a small number of micropores was observed when comparing orange peel to other adsorbents and t was considerably lower to what is recommended by ABNT NBR 12073-1991, which establishes a minimum threshold of $600 \mathrm{mg} \mathrm{g}^{-1}$. For the American Water Works Association (AWWA) the minimum iodine number is $500 \mathrm{mg} \mathrm{g}^{-1}$.

The determination of methylene blue number characterizes the adsorbent by means of its mesoporosity. The methylene blue number obtained by the method was $40 \mathrm{~mL} \mathrm{~g}^{-1}$. As observed by Baçaoui (2001), Brazil does not establish a minimum threshold for methylene blue index in coals, but in Morocco the established minimum limit is $180 \mathrm{~mL}$ of methylene blue for each gram of activated carbon, then the adsorbent orange peel showed a value for the methylene blue index below that established in Morocco for activated carbon. 


\subsection{Adsorption Capacity}

\subsubsection{Influence of $\mathrm{pH}$ on the adsorption process}

In Figure 1, it can be observed that pHs 13 and 14 presented the lowest remaining concentrations of methylene blue, being $0.306 \mathrm{mg} \mathrm{L}^{-1}$ and $0.229 \mathrm{mg} \mathrm{L}^{-1}$, respectively. However, Figure 2 shows that solutions with pHs 13 and 14 presented strongly orange color. In this way, the $\mathrm{pH} 7$ was considered favorable for adsorption, which demonstrated a remaining concentration of $0.8846 \mathrm{mg} \mathrm{L}^{-1}$, therefore presenting a dye removal of approximately $82 \%$.

Figure 1 - Remaining concentration of methylene blue

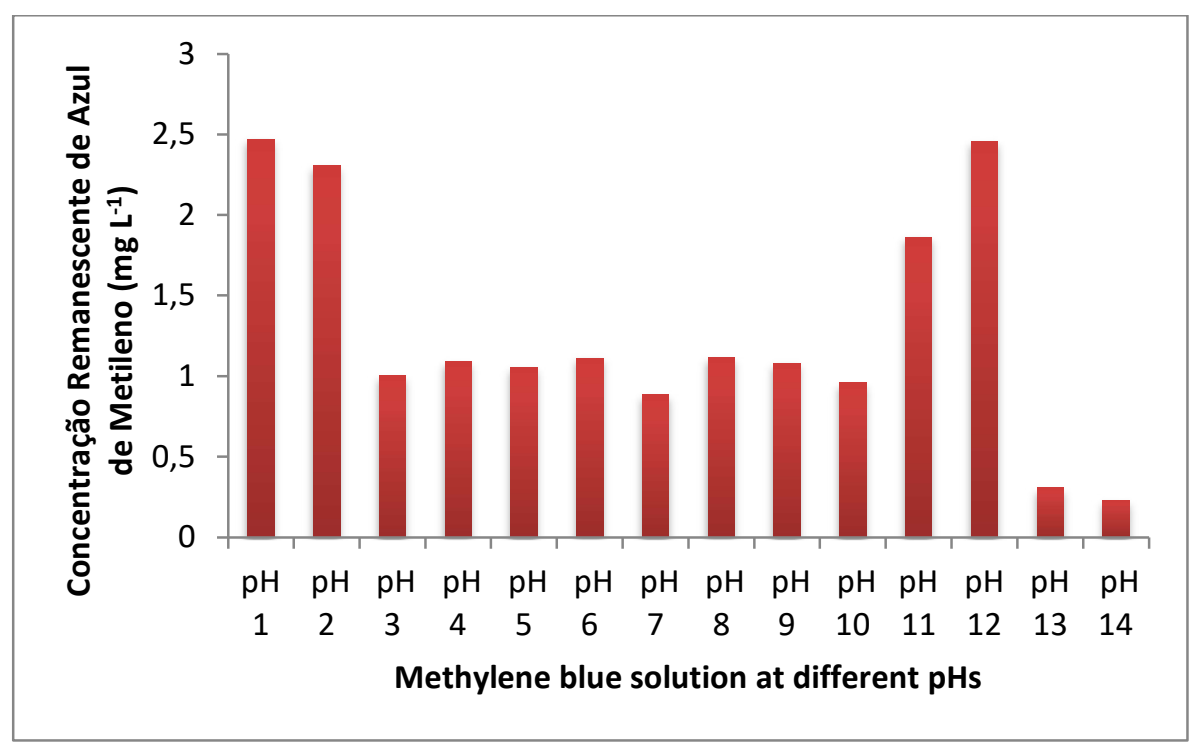

Source: Authors (2015)

Through Figure 1, it can be observed that in the acid pHs of 1 and 2 there was a low removal of methylene blue. This low removal performance in acid pHs can be associated with competition for adsorbent active sites, $\mathrm{H}+$ ions in acid solutions and methylene blue molecules, which present cationic properties. The same behavior was not observed in $\mathrm{pH}=7$ (neutral), showing that the hydrogen ions concentration in solution affects directly in methylene blue adsorption. 
Figure 2 - Remaining solution in pHs 13 and 14

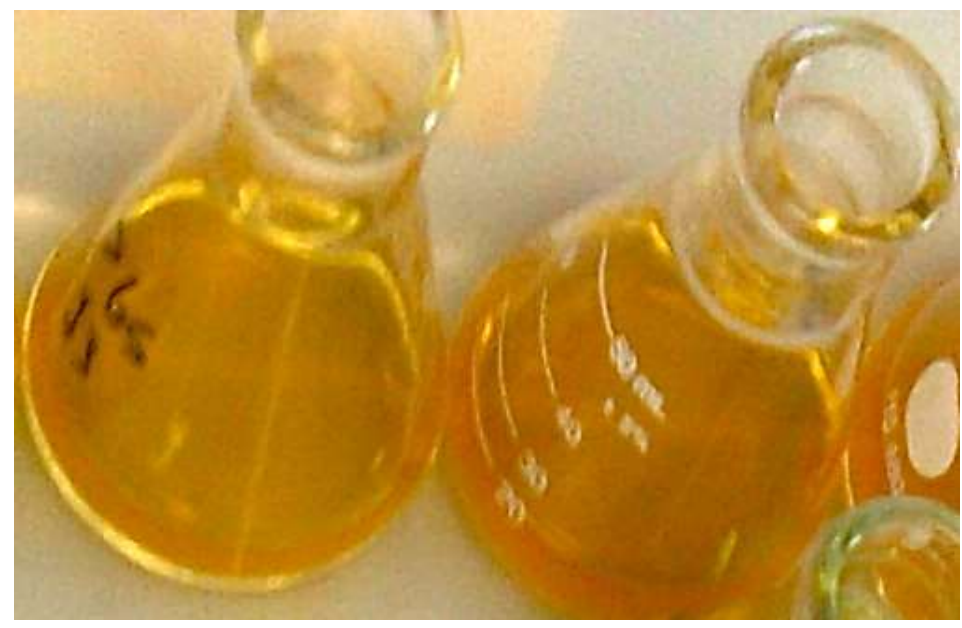

Source: Authors (2015)

The orange peel adsorbent presented maximum adsorption of $50.8 \%$ of the adsorbent (methylene blue) with a solution at $\mathrm{pH} 1$ and adsorption of $82 \%$ at favorable $\mathrm{pH}(\mathrm{pH} 7)$, for an initial condition of $5 \mathrm{mg} \mathrm{g}^{-1}$.

Figure $3(a-b-c)$ illustrates the photometric spectral scanning of methylene blue, the methylene blue solution after the adsorption process and the orange peel solution with water at $\mathrm{pH}$ 7. The choice of this $\mathrm{pH}$ value for the following studies was because methylene blue removal was more efficient at $\mathrm{pH} 7$ than at other $\mathrm{pH}$ values.

According to JIS K 1474-1991, the wavelength of methylene blue is $665 \mathrm{~nm}$, as it can be observed in Figure 3(a), and the maximum adsorption peak at pH 7 was similar to the value stipulated by the standard. The wavelength did not change with $\mathrm{pH}$ variations.

Figure 3 -Photometric spectral 

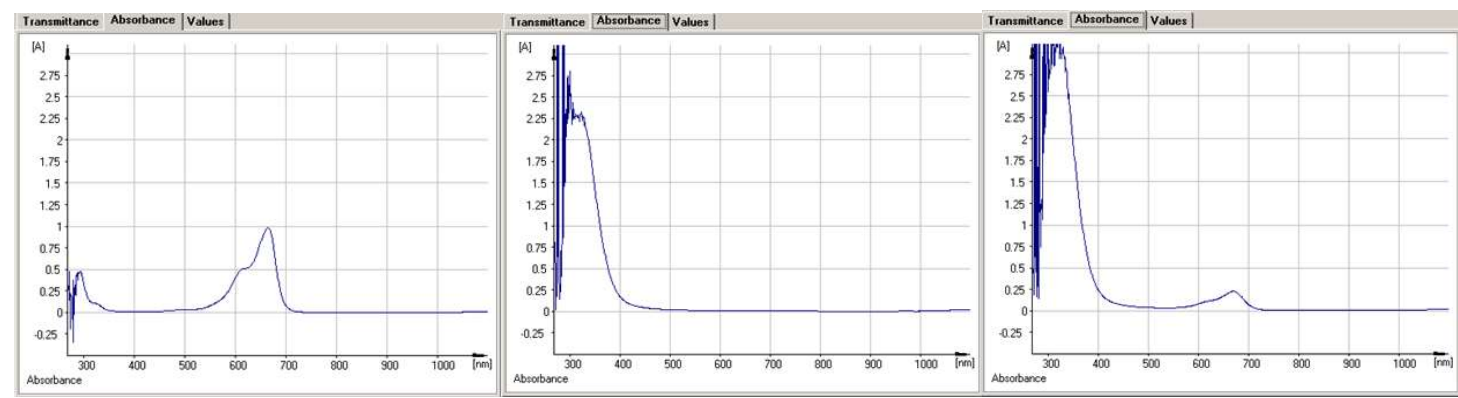

Figure 3 - (a) Photometric spectral scanning of methylene blue at pH 7. (b) Photometric spectral scanning of orange peel with water at pH 7. (c) Photometric spectral scanning of methylene blue solution after the adsorption process at pH 7.

Source: Authors (2015)

Figure 3 (b) demonstrates that the most pronounced values of absorbance for an orange solution, which corresponds to orange peel in water, were read in wavelengths different than the those that were read to the green solution, which corresponds to the mixture of orange peel + methylene blue. Therefore, it is possible to conclude that no spectral interference occurred since the photometric spectrums do not overlap.

Because the orange peel does not completely adsorb the methylene blue dye, it can be seen that the scanning spectrum, referring to the methylene blue (Figure 3 (c)), shows a peak in the wavelength.

\section{2. 2 Equilibrium time}

Table 3 presents the remaining concentration of methylene blue according to adsorption times.

The adsorption equilibrium time was determined by Student's t-test statistics and the lowest standard deviation. Observing t-test values, there was no variation between methylene blue concentrations at $10 \mathrm{~min}$ in relation to $15,25,35,50,70,100$ and $130 \mathrm{~min}$. Therefore, the equilibrium time for the adsorption process was $10 \mathrm{~min}$ interval. 
The equilibrium time found by Arami et al. (2005) for adsorption of synthetic dyes DR23 and DR80 in orange peel were similar to the equilibrium time found in this paper. On the other hand, Namasivayam et al. (1996) and Sivaraj et al. (2001) obtained an equilibrium time of $80 \mathrm{~min}$ for the adsorption of dyes congo red, procion orange, rhodamine-B and acid violet 17.

Table 3 - Remaining concentration of methylene blue

\begin{tabular}{cccccc}
\hline & Repetiti & Repetitio & Repetition & Arithmeti & Standard \\
Concentration & on 1 & $\mathrm{n} 2$ & 3 & c mean & deviation $\sigma$ \\
$\left(\mathrm{mg} \mathrm{L}^{-1}\right)$ & & & & $\bar{x}$ &
\end{tabular}

Time

(min)

\begin{tabular}{llllll}
\hline $\mathbf{1}$ & 0.8607 & 0.8730 & 1.3307 & 1.0215 & \pm 0.2678 \\
$\mathbf{3}$ & 1.0521 & 1.1699 & 1.2307 & 1.1509 & \pm 0.0908 \\
$\mathbf{5}$ & 1.0141 & 0.7994 & 0.7528 & 0.8554 & \pm 0.1394 \\
$\mathbf{1 0}$ & 0.7117 & 0.6632 & 0.7969 & 0.7239 & \pm 0.0677 \\
$\mathbf{1 5}$ & 0.8393 & 0.6748 & 0.8816 & 0.7986 & \pm 0.1092 \\
$\mathbf{2 5}$ & 0.8779 & 0.6331 & 0.8190 & 0.7767 & \pm 0.1278 \\
$\mathbf{3 5}$ & 0.8693 & 0.6282 & 0.6773 & 0.7249 & \pm 0.1274 \\
$\mathbf{5 0}$ & 0.7135 & 1.0583 & 0.5693 & 0.7804 & \pm 0.2515 \\
$\mathbf{7 0}$ & 0.6436 & 0.3963 & 0.5908 & 0.5436 & \pm 0.1302 \\
$\mathbf{1 0 0}$ & 0.9209 & 0.7006 & 0.7534 & 0.7916 & \pm 0.1150 \\
$\mathbf{1 3 0}$ & 0.8748 & 0.7153 & 0.7018 & 0.7640 & \pm 0.0962 \\
\hline
\end{tabular}

Source: Authors (2015)

3. 2. 3 Adsorption Isotherms

Figure 4 shows a plot of the linearization of Langmuir isotherm built with experimental data. 
Figure 4 - Linearization of the Langmuir isotherm for experimental data obtained

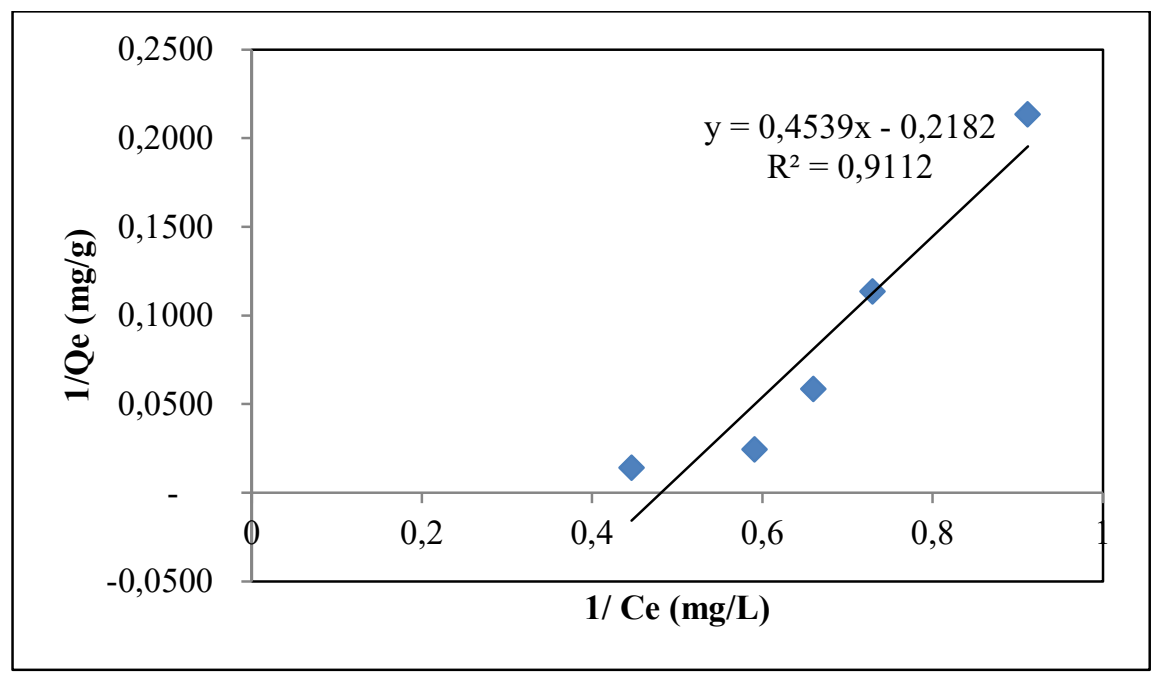

Source: Authors (2015)

From the linear equation, presented in Figure 4, the Langmuir adsorption parameters were obtained. These parameters are shown in Table 4.

Table 4 - Coefficient of determination and the parameters of Langmuir adsorption

\begin{tabular}{ccc}
\hline $\mathbf{B}$ & $\mathbf{K}_{\mathbf{l}}\left(\mathbf{L ~ m g}^{-1}\right)$ & $\mathbf{R}^{\mathbf{2}}$ \\
\hline-4.58716 & -0.48124 & 0.911 \\
\hline
\end{tabular}

Legend: $\mathrm{B}=$ constant related to the saturation capacity in monolayer; $\mathrm{K}=$ equilibrium adsorption constant.

Source: Authors (2015)

It can be observed in Table 4 that the data did not fit to Langmuir adsorption model, presenting negative constant values. Thus, the system does not follow the proposition in which the Langmuir model is based on. Fungaro et al. (2009) used a zeolitic material synthesized with charcoal ashes in an adsorption system which data did not fit to Langmuir adsorption model, therefore, showing that there is a heterogeneity on the surface or in the pores of the adsorbent that affect adsorption. 
Figure 5 shows a linearized Freundlich isotherm built with experimental data.

Figure 5 - Linearized Freundlich isotherm

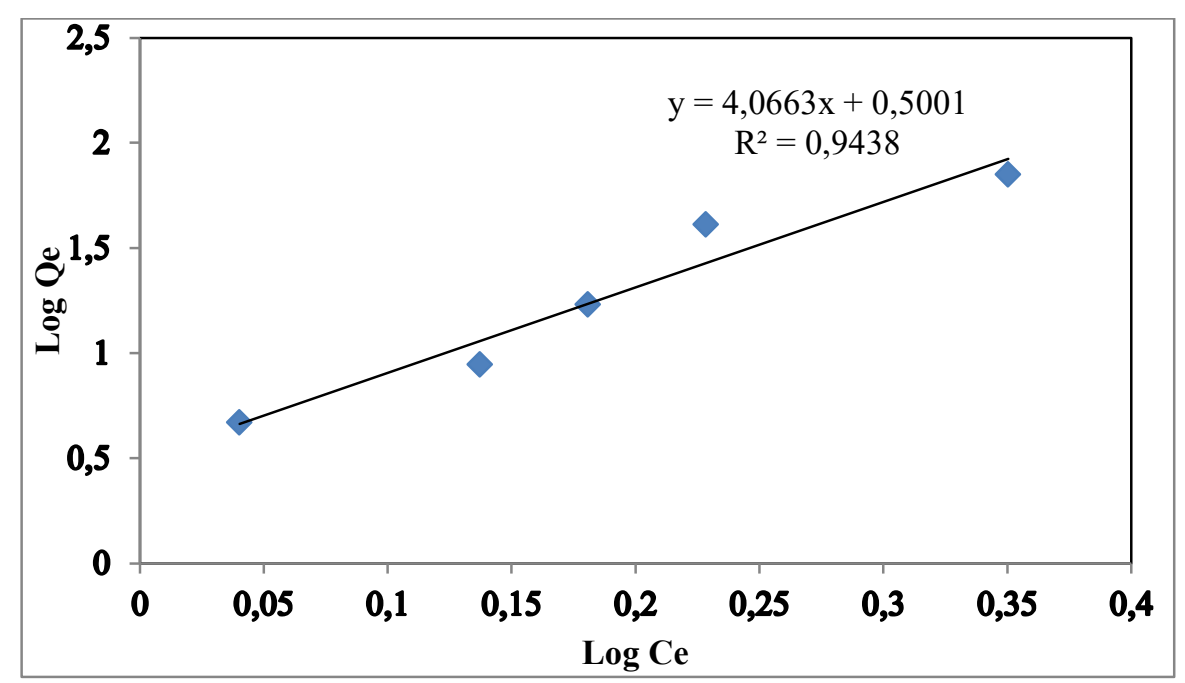

Source: Authors (2015)

The coefficient of determination value $\left(R^{2}\right)$ showed in Figure 5 was approximately equal to 1.00 , demonstrating the goodness of fit. From the linear equation, shown in Figure 5, the Freundlich adsorption parameters were obtained. The coefficient of determination and Freundlich model parameters are shown in Table 5.

Table 5 - Coefficient of determination and Freundlich model parameters

\begin{tabular}{ccc}
\hline $\mathbf{1 / n}$ & $\mathbf{K}_{\mathbf{f}}\left({\left.\mathbf{L ~} \boldsymbol{g}^{-1}\right)}\right.$ & $\mathbf{R}^{\mathbf{2}}$ \\
\hline 4.066 & 2.5293 & 0.943 \\
\hline
\end{tabular}

Legend: $1 / \mathrm{n}=$ adsorbent affinity to adsorbate; $\mathrm{Kf}=$ constant related to adsorption capacity; $\mathrm{R}^{2}$ $=$ coefficient of determination.

Source: Authors (2015)

The orange peel adsorbent present $\mathrm{K}_{\mathrm{f}}$ values much smaller than what was found by Piza (2008), which obtained $\mathrm{K}_{\mathrm{f}}$ of $370 \mathrm{~L} \mathrm{mg}^{-1}$ and $1 / \mathrm{n}$ lower than 0.21 for activated carbon, considering that the bigger the $\mathrm{K}_{\mathrm{f}}$ value the bigger is adsorption capacity and the lower the $1 / n$ value the better is the adsorbent affinity to the adsorbate. 
Freundlich model parameters resulted in an adsorption capacity, which is the adsorbed amount per unit mass of adsorbent, of $3.9630 \mathrm{mg} \mathrm{g}^{-1}$. Namasicayam et al. (1996) obtained an adsorption capacity similar to the presented in this paper, being adsorbed $1.3 \mathrm{mg} \mathrm{g}^{-1}$ and $3.22 \mathrm{mg} \mathrm{g}^{-1}$ of procion orange and Rhodamine-B respectively.

In this way, the Freundlich isotherm was the one that most adapted to the adsorption process in orange peel, being possible to consider that in the orange peel there is a structure in multilayers and the presence of heterogeneous systems in the surface or in the pores of the adsorbent.

\section{2. 4 Column chromatography}

Chromatography was performed to obtain colored compounds in solution after the adsorption process with the remaining solution of the adsorption process, as shown in Figure 6.

In part 1 of Figure 6 , it is observed that when adding the water mobile phase the yellow color, which is the color characteristic of an orange peel, separated from the solution; however, in the parts 2 and 3 of the same figure, a more detailed observation the release of yellow color. On the other hand, in part 4 of the figure only the blue color remaining in the solution is shown, that are the moving phases ethanol, toluene, ethyl acetate, hexane, but it was not possible to remove the blue color that was fixed in the stationary phase florisil. It can thus verify that the remaining solution shows greenish coloration due to the mixture of the coloration released by the orange peel and the color of the methylene blue. 
Figure 6 - Sequence of column chromatography

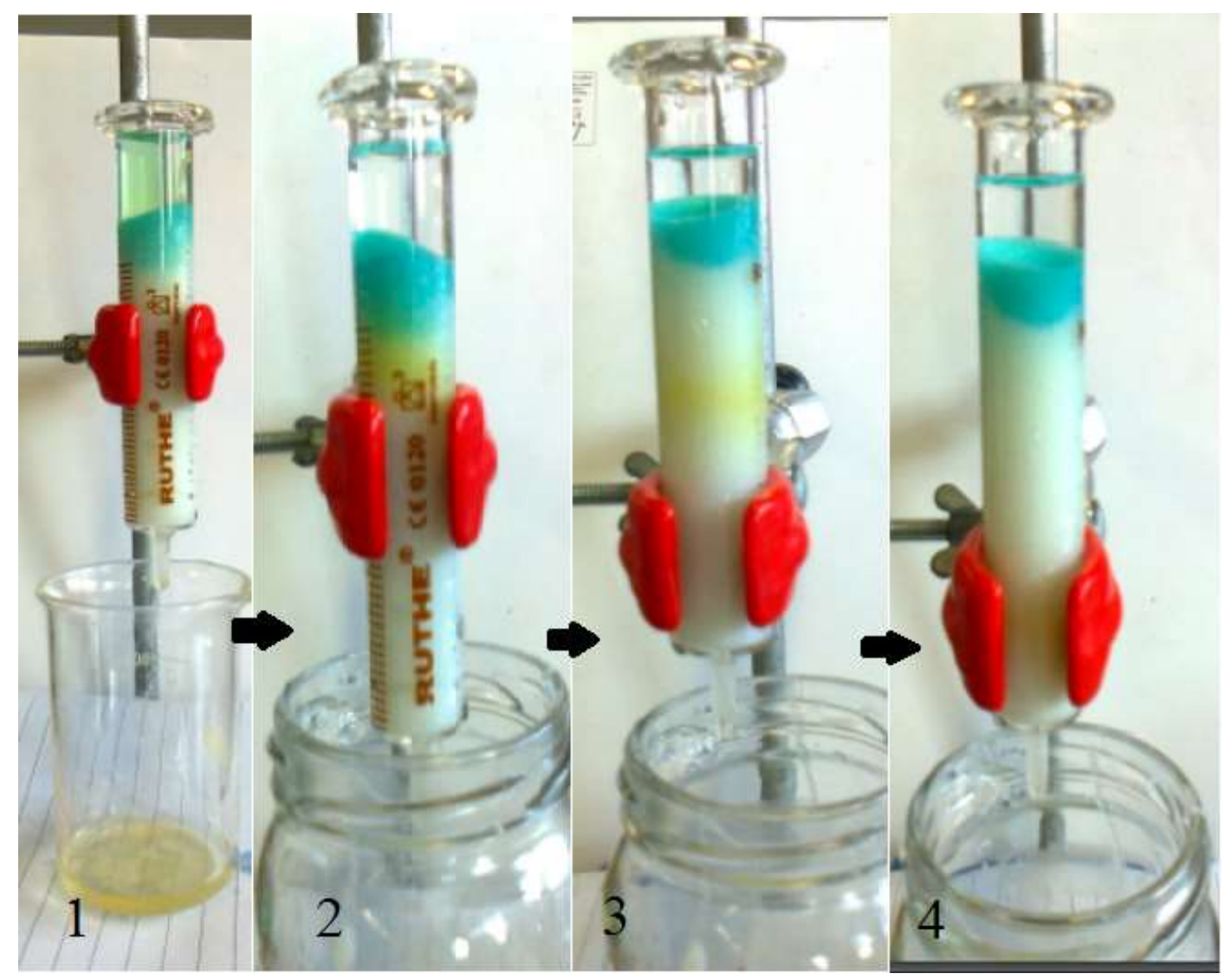

Source: Authors (2015)

\section{CONCLUSIONS}

The characterization of the adsorbent through the determination of physical and chemical parameters demonstrated that the adsorbent in natura has a high moisture content of $74.37 \%$, being thus the drying of the adsorbent indispensable before the use.

The determinations of iodine and methylene blue numbers demonstrated a difficulty in the application of standards which are not specific for the adsorbent studied.

Through the photometric spectral scanning performed in the methylene blue solutions with the orange peel at $\mathrm{pH} 7$, it was observed that the orange color does not interfere in the wavelength of methylene blue, therefore leading to the conclusion that no spectral overlap occurs, that is, no spectral interference was observed. 
With an initial concentration of $5 \mathrm{mg} \mathrm{g}^{-1}$, a removal performance of $82 \%$ of methylene blue was achieved at $\mathrm{pH} 7$.

From the application of adsorption isotherms, it is observed that the experimental data fitted only to the Freundlich equation, which presented an adsorption capacity of $3.9630 \mathrm{mg} \mathrm{g}^{-1}$ of methylene blue per gram of orange peel.

By means of adsorption study, the orange peel demonstrated to be an attractive alternative adsorbent. Further research can improve the performance of orange peel as an adsorbent since it was used in natura.

\section{BIBLIOGRAPHY}

ASSOCIAÇÃO BRASILEIRA DE NORMAS TÉCNICAS. MB-3410: Carvão ativado pulverizado determinação do número de iodo. Rio de Janeiro, 1991. 4p.

ASSOCIAÇÃO BRASILEIRA DE NORMAS TÉCNICAS. MB-3414: Carvão ativado pulverizado determinação da umidade. Rio de Janeiro, 1991. 2p.

ARAMI, M.; et al.Removal of Dyes from Colored Textile Wastewater by Orange Peel Adsorbent: Equilibrium and Kinetics Studies. Journal Colloid Interface Science, v. 288, p. 371376, 2005.

BELTRAME, L. T. C. Caracterização de Efluente Têxtil e Proposta de Tratamento. 2000. 161 f. Dissertação (mestrado em Engenharia Química) - Universidade Federal do Rio Grande do Norte. Natal, 2000

FERRARI. L. D. F. Remoção De Corante De Efluentes Da Indústria Têxtil Utilizando Processos Com Membranas E Adsorção Em Bagaço De Laranja. 2009. 166 F. Tese (Doutorado Em Engenharia Química) - Universidade Estadual De Maringá, Maringá, 2009.

FRANCISCHETTI, J. Remoção de Metais Pesados em Efluentes Líquidos Através da Filtração Adsortiva. Florianópolis, 2004. 91f. Dissertação (Mestrado em Engenharia Química) Universidade Federal de Santa Catarina.2004.

GUARATINI, C. C. I., ZANONI, M. V. B. “Corantes Têxteis”, Química Nova, v. 23, pp. 1-21. 2000.

NAMASIVAYAM, C., et al. Removal of Dyes from Aqueous Solutions by Cellulosic Waste Orange Peel. Bioresource Technology, v. 57, p. 37-43, 1996. 
ROYER, B. Remoção De Corantes Têxteis Utilizando Casca De Semente De Araucaria Angustifólia Como Biossorvente. 2008. 68 f. Dissertação (Mestrado em Engenharia Química) - Universidade Federal Do Rio Grande Do Sul - Porto Alegre, 2008.

SILVA, L. M. Estudo Da Potencialidade Dos Resíduos Do Umbu, Manga E Goiaba Como Bioadsorventes. 2012. 63 f. Dissertação (Mestrado em Engenharia de Alimentos) Universidade Estadual do Sudoeste da Bahia, Itapetinga,2012.

SIVARAJ, R., NAMASIVAYAM, C., KADIRVELU, K. Orange Peel as an Adsorbent in the Removal of Acid Violet 17 (Acid dye) from Aqueous Solutions. Waste Management, v. 21, p. 102-110, 2001.

VASQUES, A.R.; SOUZA, S.M.G.U. de; VALLE, J.A.B.; SOUZA, A.A.U. de. Application of ecological adsorbent in the removal of reactive dyes from textile effluents. Journal of Chemical Technology Biotechnology, v. 84, p. 1146 - 1155, 2009.

\section{AUthORSHIP CONTRIBUTIONS}

\section{1 - Aline Haas}

Master in environmental sciences

https://orcid.org/0000-0002-8840-213X |E-mail: eng.alinehaas@gmail.com

Contribution: Conceptualization, Data curation, investigation, Methodology, Wrting - original draft, Writing - review e editing

\section{2 - Eliane Pereira dos Santos}

Doctor in Chemistry

https://orcid.org/0000-0001-6407-6192| elianeps@ufsm.br

Contribution: Conceptualization, Formal Analysis, Spervision, Validation, Wrting - original draft, Writing - review e editing

\section{HOW TO QUOTE THIS ARTICLE}

HAAS, A; SANTOS, E. P. Characterization and application of orange peel as an adsorbent for cationic dye removal from aqueous solution, Santa Maria, v.25, e16, 2021. Available from: https://doi.org/10.5902/2236117065271. Accessed: Month Abbreviated. Day, year. 